\title{
Phenotypic plasticity and ecology of three species of Podostemaceae Rich. Ex C. Agardh
}

\author{
H. Lalruatsanga
}

Department of Botany, Pachhunga University College, Aizawl 7960or, India

\begin{abstract}
The members of Podostemaceae, commonly called river-weeds, are with very peculiar vegetative form; revealing many unique morphological, anatomical and ecological characters from other angiosperms. They undergo an annual cycle of colonization, establishment of a canopy of mature plant, and dies back when the water level drops. The annual pattern is dictated by high and low water periods. Physico-chemical analysis showed that the largest population of the species occupied an area of full sunlight. Water samples from the two study sites viz. Janiaw and Umtienger localities, both from East Khasi Hills District, Meghalaya, India, showing high $\mathrm{pH}$ indicated less human activities of different kind. It is also determined that the species inhabits clean rivers, thus, they serve as an indicator of clean water. They occur primarily in low nutrient condition. Further, it was also observed that dissolved oxygen is the most essential factor for successful establishment of these plants, rather than other nutrients and $\mathrm{pH}$. Toxic discharge of effluents from industries and agrochemical residues are serious threat to podostemads that has unique ecological requirement.
\end{abstract}

Key words: East Khasi Hills; Hydrobryum griffithii; Podostemon subulatus; Polypleurum wallichii.

\section{Introduction}

Podostemaceae Rich. Ex C. Agardh is the largest family of strictly aquatic flowering plants and consists of aquatic angiosperms that typically grow on rocks in cascades, waterfalls and rapids (Fig. 1\&2) where there are great fluctuations in the river water levels., ${ }^{1,2}$ In nature, flowering commences in September and the flowers are differentiated when the plants are still submerged. Fruit maturation takes place when the water level drops and the rocks become gradually exposed. The populations undergo an annual cycle of colonization, establishment of a canopy of mature plant, and die back when the water level drops (Fig. 3\&4). Meijersuggested that the occurrence of river-weed is an indicator of good water quality. ${ }^{3}$

Podostemaceae display a variety of morphological, anatomical and ecological characteristics and stood clearly apart from all other angiosperm families. They occur in an unusual habitat for angiosperm, tenaciously attached to substrata in torrential currents of waterfalls and river-rapids. The nature of habitat is associated with unusual morphology and phenotypic plasticity. ${ }^{5}$ Podostemaceae are confined ecologically to rapid river habitats and their high global diversity evades explanation.

Podostemaceae grow in rivers and streams 
that have a seasonal high-low water cycle. Cataracts and waterfalls are typical habitats; they are reported to occur only in the areas of rapids, where they tolerate current speeds of $2-3 \mathrm{~m} / \mathrm{s}^{-1}{ }^{6}$ Various authors have suggested that water turbulence provides the aeration needed for gas uptake by these plants. ${ }^{7-9}$ The plants are haptophytes, i.e., plants that attach to, but do not penetrate, a solid substratum. ${ }^{10}$ The vegetative plant body grows submerged during the rainy season, flowering is initiated when the level of water drops and plants are exposed (Fig. $5 \& 6) .{ }^{11,12}$ In podostemaceae, anthesis is generally believed to take place only after the flower buds are exposed by the dropping water level..$^{13-15}$

All these unusual and typical characteristics necessitate the examination of habitats and its physico-chemical properties, which restrict the plant to only very few sites. Particulars given are the ecological conditions and chemical assays of the aquatic habitat of this enigmatic family

\section{Materials and Methods}

Flowers of Hydrobryum griffithii (Wall. ex Griff.) Tul., Podostemon subulatus Gard and Polypleurum wallichii (R. Br. ex Griff.) Warm., at various stages were collected from Janiaw locality, Mawsynram and Umtienger locality, both from East Khasi Hills, Meghalaya state, India (lat-long: $25.2975 \mathrm{~N}$ 91.5826E \& 25.5840N 91.9003E respectively). Water samples from the two sites were collected and analyzed in the laboratory. All the chemicals were of AR (analytical reagent) grade. Double distilled water was used for the preparation of reagents and solutions. The experimental details of parameters considered for assessment of habitats are given below:

Temperature: Temperature measurements have been made with mercury filled $110^{\circ} \mathrm{C}$ bulb thermometer in a natural stream, the reading of which taken after 2 minutes of dipping to a depth of about $30 \mathrm{~cm}$.

$\mathrm{pH}$ : The $\mathrm{pH}$ of water sample was measured by electronic method. The $\mathrm{pH}$ meter was calibrated with standard buffer solutions viz. potassium hydrogen phthalate $(0.05 \mathrm{M} ; \mathrm{pH}=4.01)$ and borax (0.01 M; pH= 9.14).
Total Alkalinity: Total alkalinity of water is normally due to the presence of bicarbonate, carbonate and hydroxide salts. It is determined by volumetric method and expressed as $\mathrm{CaCO}_{3}$ $\mathrm{mg} / \mathrm{l}$.

$1 \mathrm{ml}$ of $0.02 \mathrm{~N} \mathrm{H}_{2} \mathrm{SO}_{4}=1 \mathrm{mg}$ of $\mathrm{CaCO}_{3}$

Total alkalinity $=($ Titre value $\times 1000 / 25) \mathrm{mg}$. $\mathrm{CaCO}_{3} / \mathrm{l}$.

Chloride: Chloride content of water sample was determined volumetrically by argentometric method. From the titre value the amount of chloride ions present in the sample was calculated and expressed in terms of $\mathrm{mg} / \mathrm{l}$.

Total hardness: The total hardness of water is due to the presence of soluble salts of calcium and magnesium ions. It is estimated by complexometric method (sometimes chelatometry) using disodium salt of ethylene diamine tetra acetic acid (EDTA) as complexing method. From the end point, the total hardness of a sample was calculated and is expressed as $\mathrm{CaCO}_{3} \mathrm{mg} / \mathrm{l}$.

Dissolved Oxygen: The dissolved oxygen content was measured using iodometric method. The liberated iodine was titrated against sodium thiosulphate $(0.025 \mathrm{~N})$ solution using starch as indicator. From the end point, the amount of dissolved oxygen was calculated.

Biological Oxygen Demand: The sample was kept in an incubator at $20^{\circ} \mathrm{C}$ for five days. The dissolved oxygen in the incubated sample has been measured as per the procedure discussed above.

\section{Results}

The analysis of water collected from the stream near Umtienger, about $22 \mathrm{kms}$ away from Shillong, harboring Podostemon was given under. The plants grow on submerged granitic rocks in fast flowing rivers and cataracts.

Again, an assay of water examined during the flowering season from the river at fossil park, Janiaw, in Lawbah region; about $6 \mathrm{~km}$ away from Mawsynram, inhabited by Polypleurum and Hydrobryum, was examined in the same parameters employed with the stream near Umtienger.

Temperature and $\mathrm{pH}$ : Temperature reading of the samples during the period of investigation 
is observed in the range of 9 and $10^{\circ} \mathrm{C}$ respectively. The samples from site-I have $\mathrm{pH}$ of 6.84 containing no carbonates but bicarbonates and carbonic acids.

On the other hand, site-II has a pH of 8.68 containing carbonates with or without bicarbonates; they do not have free carbonic acids. The $\mathrm{pH}$ data show that the waters are slightly basic which is attributed to less human activities such as biological and chemical waste disposal.

Total alkalinity: The determination of total alkalinity (TA) gives an idea of salt present in water samples. In general, if alkalinity is greater than hardness, in addition to calcium and magnesium salts, basic sodium and potassium salts are also present.

From the Tables 1 \& 2, total alkalinity far exceeds the total hardness in both the sites, viz. 26:2 in site-I and 88:0 that indicates that the water is very rich in salt contents.

$\mathrm{Cl}, \mathrm{NO}_{2}, \mathrm{Fe}, \mathrm{PO}_{4}$ and $\mathrm{SO}_{4}$ contents: The data shown in table $1 \& 2$ shows the reading of title parameters for both the sites. It is very interesting to see that both the sites have low contents of above parameters compared to other streams of the state.

Total hardness: Total hardness (TH) is defined as the reluctance of water to give lather with soap. According to the classification of water based on $\mathrm{TH}$, waters with hardness below 50 are soft water; the two study sites have very low TH i.e., 2.0 \& 0 respectively. Since calcium and magnesium are the principal cations causing hardness, the two study sites are very poor in calcium and magnesium contents.

Dissolved oxygen: Dissolved oxygen is a measure of the corrosiveness of water, photosynthetic activity and septicity of water. Respiration by plants and animals reduces oxygen concentration, while photosynthetic activity of plant increases it. The DO is considerably high in the two sites, 11.6 and 5.5 respectively.

Biological oxygen demand: BOD is a test of great value in the analysis of sewage and grossly the extent of pollution. The two sites have BOD of $4.0 \& 2.0 \mathrm{mg} / \mathrm{l}$ respectively. As per the Royal Commission classification, Site-I falls under
"Fairly Clean" whereas Site-II with a BOD of 2.0 is regarded as "Clean" with lesser influence of pollution.

Productivity: Productivity is the rate at which radiant energy is stored by photosynthetic and chemosynthetic activity of producer organisms. Two sites have fairly high productivity i.e., 7.23/ 7.1 and 6.51/ 6.36 respectively. The clarity of water and light intensity may account for high productivity and the data reveals the active photosynthetic activity of the plants.

\section{Discussion}

In the present study, various physicochemical parameters were analyzed and correlated with the ecology of Podostemaceae. Total hardness is very low (2.0 \& 0 respectively) in contrast to the rivers of Kerala, ${ }^{16}$ and black water rivers of Venezuela, as well as some rivers of Mexico, ${ }^{17}$ indicating low content of calcium and magnesium. Quiroz et al ${ }^{17}$ sampled twenty-eight tropical rivers in which Podostemaceae occurs from the Mexican states of Nayarit, Jalisco, Guerrero and Oaxaca on the Pacific slope, and Vera Cruz and Oaxaca on the Atlantic slope; seventeen rivers had nutrient levels below the level of detection; six rivers had detectable levels of total nitrogen $(0.160-2.05 \mathrm{mg} / \mathrm{l})$ and total phosphorus $(0.10-0.72 \mathrm{mg} / \mathrm{l})$. Contents of nutrients like $\mathrm{Cl}^{-}$, $\mathrm{Ca}, \mathrm{Mg}, \mathrm{NO}_{2}, \mathrm{Fe}, \mathrm{PO}_{4}$ and $\mathrm{SO}_{4}$ are considerably low in the two study sites compared to Kerala rivers with $\mathrm{SO}_{4}: 1.1 \mathrm{mgl}^{-1} ; \mathrm{NO}^{2}: 16 \mathrm{mgl}^{-1} ; \mathrm{Mg}: 1.6 \mathrm{mgl}^{-1}$ to $4 \mathrm{mgl}^{-1}$ which indicates that the plant primarily occurred in low nutrient (oligotrophic) rivers. ${ }^{16}$

Astonishingly, $\mathrm{pH}$ of the study sites also varied from those of New World such that 6.84 and 8.68 respectively but ranging from 7.1 to 9.1 in Mexican rivers and 4.7 and 4.8 in the black water river Caroni. The two sites having high pH indicate less human activities of different kind. With the assays of BOD, it is well established that Podostemaceae inhabits clean rivers with less pollution and human influences. Meijer ${ }^{3}$ suggests that the occurrence of riverweed is an indicator of good water quality. The family has no known specific economic value, but serves as an indicator of clean water 
Table 1 | Physico-chemical properties of water collected from Umtienger.

\begin{tabular}{clc|}
\hline SI. & Parameters & Result \\
\hline 1 & Temperature & $9^{\circ} \mathrm{C}$ \\
\hline 2 & $\mathrm{pH}$ & 6.84 \\
\hline 3 & Alkalinity $(\mathrm{mg} / \mathrm{I})$ & 26.0 \\
\hline 4 & Total hardness $(\mathrm{mg} / \mathrm{I})$ & 2.0 \\
\hline 5 & Dissolved Oxygen $(\mathrm{mg} / \mathrm{I})$ & 11.60 \\
\hline 6 & Chloride $(\mathrm{mg} / \mathrm{I})$ & 10.65 \\
\hline 7 & $\mathrm{~B} . \mathrm{O}^{\mathrm{D}}(\mathrm{mg} / \mathrm{I})$ & 4.0 \\
\hline 8 & $\mathrm{NO}_{2}(\mathrm{mg} / \mathrm{I})$ & 0.009 \\
\hline 9 & $\mathrm{PO}_{4}(\mathrm{mg} / \mathrm{I})$ & 0.004 \\
\hline 10 & $\mathrm{SO}_{4}(\mathrm{mg} / \mathrm{I})$ & 1.088 \\
\hline
\end{tabular}

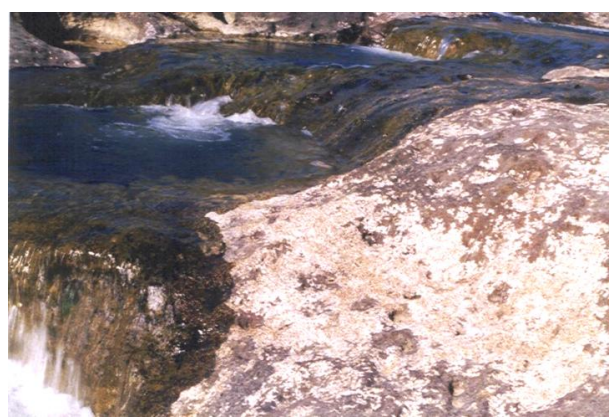

Fig. 1 | Habitat of Hydrobryum griffithii.

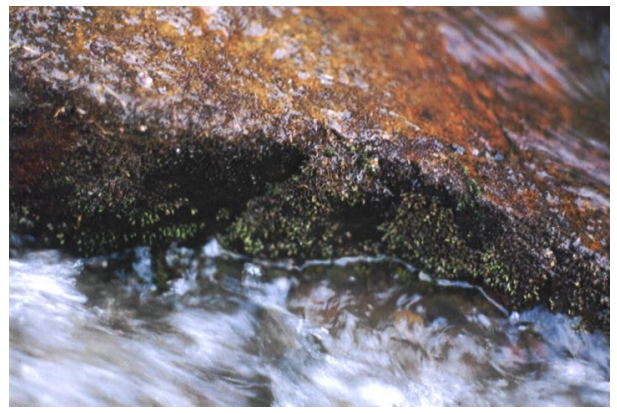

Fig. 3 | Habitat of Podostemum subulatus.

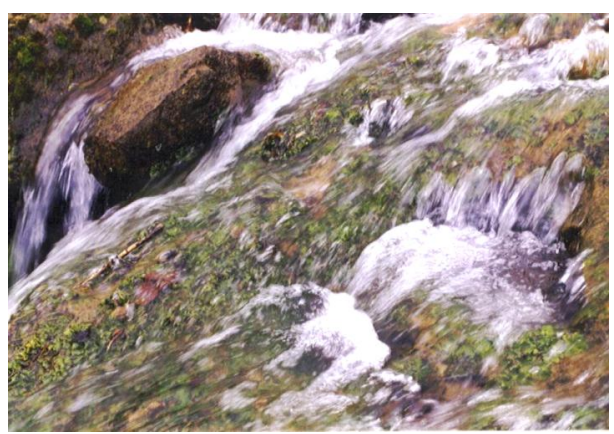

Fig. 5 | Habitat of Polypleurum wallichii.
Table 2 | Physico-chemical properties of water collected from Janiaw.

\begin{tabular}{|clc|}
\hline Sl. & Parameters & Result \\
\hline 1 & Temperature & $10^{\circ} \mathrm{C}$ \\
\hline 2 & $\mathrm{pH}$ & 8.68 \\
\hline 3 & Alkalinity $(\mathrm{mg} / \mathrm{l})$ & 88.0 \\
\hline 4 & Total hardness $(\mathrm{mg} / \mathrm{l})$ & 0 \\
\hline 5 & Dissolved Oxygen $(\mathrm{mg} / \mathrm{l})$ & 6.5 \\
\hline 6 & Chloride $(\mathrm{mg} / \mathrm{l})$ & 10.80 \\
\hline 7 & $\mathrm{~B} . \mathrm{O} . \mathrm{D}(\mathrm{mg} / \mathrm{l})$ & 2.0 \\
\hline 8 & $\mathrm{NO}_{2}(\mathrm{mg} / \mathrm{l})$ & 0.007 \\
\hline 9 & $\mathrm{PO}_{4}(\mathrm{mg} / \mathrm{l})$ & 0.156 \\
\hline 10 & $\mathrm{SO}_{4}(\mathrm{mg} / \mathrm{l})$ & 2.902 \\
\hline
\end{tabular}

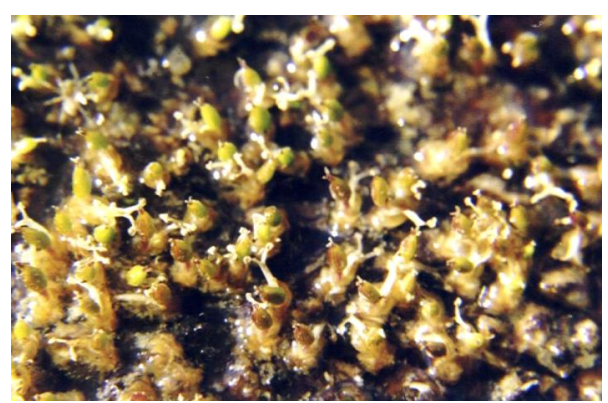

Fig. 2 | H. griffithii flowering soon after water recedes.

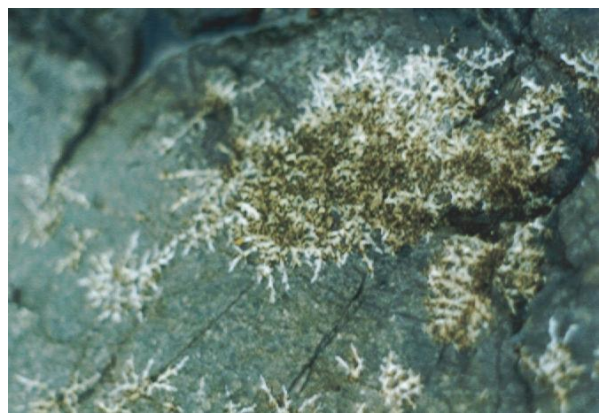

Fig. 4 | Dried thallus of $P$. subulatus at the season end.

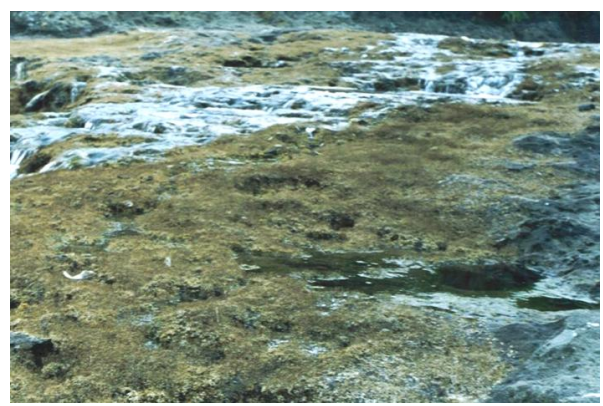

Fig. 6 | Dried plants of $P$. wallichii at the season end. 
The assays on the productivity reveal that the two sites have considerable high productivity viz. 7.23/ 7.1 and 6.51/ 6.36 respectively. As far as known, Podostemaceae are not able to use the carbonate dissolved in water for photosynthesis. ${ }^{18}$ The high productivity reveals the massive contribution of dissolved oxygen in the system. The feeble decrease in net productivity from gross productivity may accounts for less respiratory activities; it may either be because of the swift water currents.

However, the content of dissolved oxygen in the water of all rivers examined are quite high and falls in the same range with Kerala rivers and of Rio Caroni (6.5-11). The rivers in the study site are fast flowing and well oxygenated. The result shows that the dissolved oxygen (and carbon dioxide dissolved in water) is the most essential factor for the successful establishment of these plants, rather than the content of other nutrients and the $\mathrm{pH}$. At the same time, it is also established that Podostemaceae involve much in photosynthetic activity and biochemical processes. A lack of lacunar tissue in podostemads likely is associated with the highly aerated water in which they occur. ${ }^{19-21}$

Bell122 studied the effect of effluents of rubber factory in Kanyakumari district in Tamil Nadu, India, and has observed the elimination of three species of Podstemaceae in the downstream due to acidic discharges. Predictions regarding global warming may also adversely affect podostemads as they occur in seasonally pulsating rivers. 1,23 $^{2}$

Since the habitat is particularly susceptible to human impact, podostemads are subjected to a wide range of anthropogenic disturbances. Toxic discharge of effluents from industries and agrochemical residues are serious threats to the podostemads that have a unique ecological requirement. It is predictable that river weeds are detrimentally impacted by factors that influence the seasonality of the water level, attachment to solid substrata, and light availability. For example, dam building changes the high-low seasonal water pattern and no doubt leads to loss of populations in flooded regions of rivers. Nutrient pollution (e.g. from agriculture and domestic sources) can lead to increased algae cover, which decreases light availability. It is therefore imperative to evolve strategy for conservation concern in ex and in situ conditions.

\section{Acknowledgement}

The author is extremely indebted to Prof. N. Venugopal for kind supervision; thankful to Prof. N. K. Churungoo, the then Head of Botany Department, NEHU, Shillong for providing Facilities and also to University Grants Commission, New Delhi, for grant of Research fellowship.

\section{References}

I. Philbrick, C.T. \& Novelo, A.R. (1995). New World Podostemaceae: ecological and evolutionary enigmas. Brittonia 47, 210-222.

2. Cook, C.D.K. (1996). Aquatic and Wetland Plants of India. Oxford University Press, Oxford, pp. 316-325

3. Meijer, W. (1976). A note on Podostemum ceratophyllum Michx. as an indicator of clean streams in and around the Appalachian Mountains. Castanea 4I, 319332

4. Herr, J.M. (1984). Embryology and Taxonomy. In: Embryology of Angiosperms (B.M. Johri, ed). Springer, Berlin, Heidelberg, New York, pp. 647-696.

5. Rutihauser, R. (1997). Structural and developmental diversity of Podostemaceae (riverweeds). Aquatic Botany $57,29-70$.

6. Neiff (1986). Aquatic plants of Parana System. In: The Ecology of River Systems (K.F. Walker \& B.R. Davies, eds), Dr. W. Junk Publishers, The Netherlands, pp. 55757I.

7. Gessner, F. \& Hammer, L. (1962). Okologisch- physiologische Untersuchungen an den Podostemaceen des Caroni. Hydrobiologia 47, 497-54I.

8. Grubert, M. (1976). Podostemaceen - Studien, Teil II. Untersuchungen uber die Keimung. Botanische Jabrbucher fur Systematic 95, 455-477.

9. Sculpthore, C.D. (1967). The Biology of Aquatic Vascular Plants. Edward Arnold, London.

Io. Luther, H. (1949). Vorschlag zu einer okologischen Grundeinleitung der I Iydrodophyten. Acta Botanica Fennica 44, I-I5.

II. Accorsi, W.R. (1953). Biology and ecology of the Podostemonaceae of the Piracicaba Fall. In: Proceedings of $7^{\text {th }}$ International Botanical Congress, Stockholm. pp. 68I 
-682 .

I2. van Royen, P. (195I). The Podostemaceae of the New World. Part I. Mededelingen van het botanisch museum en herbarium van de rijksuniveriteit utrech 107, 127-I5I.

13. Went, F.A.F.C. (1929). Morphological and histological peculiarities of the Podostemonaceae. In: Proceedings of International Congress of Plant Sciences, Ithaca I, 5I-358

I4. Willis, J.C., (1902a). A revision of the Podostemaceae of India and Ceylon. Annals of Royal Botanical Gardens, Peradenyia $\mathbf{I}, \mathbf{1} 8 \mathrm{I}-250$.

15. Willis, J.C., (1902b). Studies in the morphology and ecology of Podostemaceae of Ceylon and India. Annals of Royal Botanical Gardens, Peradenyia I, 267-465.

16. Mathew, C.J., Nileena, C. J. \& Jager Zurn, I. (2003). Morphology and ecology of two new species of Polypleurum (Podostemaceae) from Kerela, India. Plant Systematic and Evolution 237, 209-217

17. Quiroz, A.F., Alejandro Novelo, R, Thomas Philbrick, C. (1997). Water Chemistry and the distribution of Mexican Podostemaceae: a preliminary evaluation. Aquatic Botany 57, 15I-182
I8. Pannier, F. (1960). Physiological responses of Podostemaceae in their natural habitat. Internationale Revue der Gesamten Hydrobiologie 4, 347-354

19. Arber, A. (1920). Water Plants: A study of Aquatic Angiosperms. Cambridge University Press, Cambridge, U.K. pp. 436

20. Metcalfe, C.R., Chalk, L. (1950). Anatomy of Dicotyledons, Vol. II. Oxford, Clarendon Press.

2I. Sculpthore, C.D. (1967). The Biology of Aquatic Vascular Plants. Edward Arnold, London.

22. Bell, C.D. (1990). Biomonitoring the effect of rubber factory effluent on hill stream in Kanya Kumari District. Geobios 17, 220-222.

23. Grimm, N.B. (1993). Implications of Climate change on stream communities, In: Biotic Interactions and Global Change (P.M. Karieva, J.Q. Kingslover \& R.B. Huey, eds), Sinaeur, Sunderland: M.A, pp. 293-314. 